Article

\title{
Back to the Future? Lessons of Differentiated Integration from the EFTA Countries for the UK's Future Relations with the EU
}

\author{
Sieglinde Gstöhl ${ }^{1, *}$ and Christian Frommelt ${ }^{2}$ \\ 1 Department of EU International Relations and Diplomacy Studies, College of Europe, Dijver 11, \\ BE-8000 Bruges, Belgium \\ 2 Department of Political Science, Liechtenstein Institute, St. Luziweg 2, LI-9487 Bendern, Liechtenstein; \\ christian.frommelt@liechtenstein-institut.li \\ * Correspondence: sieglinde.gstoehl@coleurope.eu; Tel.: +32-50-477252
}

Received: 3 September 2017; Accepted: 7 October 2017; Published: 13 October 2017

\begin{abstract}
The decision of the United Kingdom (UK) to withdraw from the European Union (EU) raises the question of how to shape their post-Brexit relations. The EU has developed various forms of external differentiated integration with neighbouring countries, whereby the members of the European Free Trade Association (EFTA) enjoy the most far-reaching access to the internal market. This article discusses the conditions under which the UK could join EFTA, the EFTA countries' European Economic Area with the EU, or a similar arrangement. In light of the UK's desire to conduct an independent trade policy, to contain immigration, and to take back control of laws, lessons are drawn from EFTA's experience for trade, the free movement of persons, and institutional issues.
\end{abstract}

Keywords: Brexit; differentiated integration; European Economic Area (EEA); European Free Trade Association (EFTA); single market; free movement of persons

\section{Introduction}

On 23 June 2016, voters in the United Kingdom (UK) decided by $51.9 \%$ to $48.1 \%$ that their country should leave the European Union (EU). Whereas clear majorities in England (73\%) and Wales $(71.7 \%)$ voted to leave, majorities in Northern Ireland (55.8\%), Scotland (62\%) and Gibraltar $(95.9 \%)$ were in favour of remaining in the EU (Phinnemore and McGowan 2016, p. 7). The referendum has revived the debate on differentiated integration in Europe and, more specifically, on how the UK can organize its future relations with the EU. In the debate, references have been made to the 'Swiss model', the 'Norwegian model', and even to Liechtenstein's 'special solutions', in particular in relation to the free movement of persons (see, for instance, Burke et al. 2016; Emerson 2016; Phinnemore and McGowan 2016, pp. 19-28; Springford 2017). These countries are currently, together with Iceland, members of the European Free Trade Association (EFTA). The UK, a founding member of EFTA in 1960, had left the association in 1973 in order to join the European Community (EC).

The EFTA countries are closely associated with the EU's internal market-'an area without internal frontiers in which the free movement of goods, persons, services and capital is ensured' (Art. 26(2) of the Treaty on the Functioning of the European Union (TFEU)) - through either a plethora of bilateral agreements, as in the Swiss case, or membership in the European Economic Area (EEA). For some observers, they appear to enjoy more sovereignty than an EU member, for instance in the conduct of their own trade policy or because they seemingly are outside the reach of supranational institutions like the European Commission or the European Court of Justice (ECJ). This raises the question as to whether and under which conditions the UK, or even parts thereof, could go 'back to the future' and 
(re-)join EFTA and/or the EEA or achieve a similar bespoke arrangement with 'a new framework that allows for a close economic partnership' (May 2017c).

Since the Brexit vote, a number of British politicians have again been floating the idea that the UK could remain in the single market while leaving the EU. The Scottish Government $(2016$, p. 3) argued that the UK should stay in the internal market as a member of the EEA and within the EU customs union. Alternatively, Scotland should remain in the single market even if the rest of the UK would leave. In the latter case, Scotland would become 'a full or associate member of EFTA' and, thereafter, join the EEA or 'enter a direct association with the EEA' (Scottish Government 2016, p. 29). Similar ideas were put forward for Northern Ireland (see Doherty et al. 2017). Also the Welsh Government (2017, p. 6) came out in favour of a 'soft Brexit', stressing that the UK should search for 'full and unfettered access to the Single Market for goods, services and capital' by way of membership of EFTA, of the EEA or through 'a negotiated bespoke arrangement unique to the UK'. The International Trade Committee of the House of Commons (2017, p. 4) recommended that the government evaluate the implications of the UK rejoining EFTA, and possibly EFTA's free trade agreements (FTAs) with third countries.

On 29 March 2017, the British government triggered Article 50 of the Treaty on European Union (TEU), starting the clock for two years to negotiate 'a deep and special partnership' with the EU in economic and security co-operation and 'a bold and ambitious Free Trade Agreement' (May 2017b). Although in her Lancaster House speech on 17 January 2017, Prime Minister Theresa May had made clear that 'an independent, self-governing Global Britain' was not seeking any 'model already enjoyed by other countries' (May 2017a), this article discusses the internal market lessons to be learned from EFTA's differentiated integration for post-Brexit EU-UK relations, since any 'close economic partnership [ ... holding] rights and obligations in a new and different balance' will to a certain extent be based on the EU acquis (May 2017c). In other words, the lessons to be learned from EFTA are relevant for any advanced form of external differentiated integration. Moreover, after the general election of 8 June 2017, which resulted in a weakening of the Conservative government, 'soft Brexit' scenarios have gained traction again and the government acknowledged the need of a transition period of around two years (May 2017c).

We argue that the case of the EFTA states shows that a far-reaching participation in the internal market which excludes immigration from the EU, as envisaged by the British Leave campaign, is not a realistic option. Moreover, for the sake of market homogeneity, any dynamic form of deep and comprehensive integration requires an efficient institutional set-up for taking over relevant new EU acts and case law and for ensuring the surveillance and enforcement of these obligations. Indeed, the article shows that even the highly institutionalized EEA suffers from shortcomings, such as an inconsistent selection and a delayed incorporation of new EEA-relevant EU secondary law, falling short of market homogeneity. On the other hand, the EFTA states often lack the possibility to protect their sovereignty and regulatory preferences, as the EEA Agreement grants them only a limited participation in the EU policy-making based on the so-called 'decision-shaping', a 'process of contributing to and influencing policy proposals up until they are formally adopted' (EFTA Secretariat 2009, p. 20). Finally, EFTA (associate) membership alone would be of limited value to the UK.

The next section will briefly present the framework of analysis before the UK's key preferences are identified and the EFTA lessons for each of them are discussed.

\section{Conceptual Framework}

Leuffen et al. (2013, pp. 17-18) distinguish internal differentiation, where EU rules do not apply uniformly to all member states, from external differentiation, where non-member states also take over the EU acquis. These non-members do so either by way of adopting 'mirror legislation', like in the EEA and Schengen area, or based on the principle of equivalence of law, as in the case of most EU-Switzerland agreements. In a nutshell, external differentiation describes a formal opt-in of a non-member state into a specific policy area of the EU. In this way, the EU and the respective country define common rights and obligations for their citizens and businesses. The extent and specificity of 
those obligations are usually shaped by the scope and institutionalization set out in the agreement itself. The EU's neighbourhood is characterized by patterns of external differentiated integration, which vary not only with regard to the sectors covered in the internal market but also the degree of institutionalization (Gstöhl 2015). Among these 'models' are the EEA, the bilateral Swiss approach, the Turkish customs union, EFTA membership (or association) or partly acquis-based FTAs, such as those with some countries of the European Neighbourhood Policy like Ukraine.

With the EFTA states, the EU has concluded various bilateral agreements, but over $90 \%$ of the references to EU secondary law contained in these are part of the EEA Agreement which applies to Norway, Iceland and Liechtenstein (Frommelt 2017). The EU considers the EEA 'the most far-reaching and comprehensive instrument' to extend its internal market to third countries (European Commission 2012, p. 3). It has, thus, also been referred to as a 'single market-minus' (Pelkmans and Böhler 2013, p. 2).

Treating Switzerland as a case of external differentiated integration, Jenni (2016) finds, with regard to federal laws, that the incorporation of EU rules has been a steady characteristic since the 1990s, either based on 'autonomous adaptation' or the implementation of bilateral sectoral agreements. Similar to the EEA, the sectoral agreements cover substantial parts of the EU's internal market. Although less far-reaching, the integration process based on the Switzerland-EU agreements covers similar sectors to the EEA Agreement. In addition to this formal, legal integration, all four EFTA states have become highly Europeanized (see Frommelt and Gstöhl 2011; Gava and Varone 2014; Jónsdóttir 2013; Norwegian EEA Review Committee 2012).

Based on a brief analysis of the UK's preferences with regard to its future relationship with the EU internal market, this article examines to what extent 'a deep and special partnership' is possible in light of the lessons learned by the EFTA countries with regard to trade in goods and services, the free movement of persons, and institutional questions. The analysis draws on a comprehensive empirical assessment of the agreements between the EU and the EFTA states and the related secondary legislation (Frommelt 2017). The dataset contains specific information on the EEA decision-making process, such as the EEA relevance of an EU act, its legal basis, or the time required to its incorporation into the EEA Agreement.

\section{UK Preferences: 'Leave' the EU but 'Remain' Close to the Single Market}

In reaction to the 'hot issues' of the referendum campaign, which concentrated on the internal market rather than the Common Foreign and Security Policy (CFSP), the UK government identified three specific 'red lines' for its post-Brexit relations with the EU: (1) conducting an independent British trade policy; (2) containing immigration to Britain from Europe; and (3) taking back control of laws and the interpretation thereof.

First, the British government wants to withdraw from the EU's customs union and common commercial policy (UK Government 2017, pp. 35, 42). In the words of the Prime Minister, 'I want Britain to be able to negotiate its own trade agreements. But I also want tariff-free trade with Europe and cross-border trade there to be as frictionless as possible' with 'the greatest possible access to the single market' (May 2017a). Her notice of withdrawal letter acknowledged that membership of the internal market was not on the table since 'the four freedoms of the single market are indivisible and there can be no "cherry picking"' (May 2017b).

The UK will thus have to develop a national trade policy, including autonomous instruments such as anti-dumping procedures or preferences for developing countries and its own position in the World Trade Organization (WTO). As a member of the WTO, the UK plans to 'replicate as far as possible' the EU's tariff schedules and commitments, while it hopes to somehow continue the EU's trade agreements with non-EU countries, 'to strike deals better suited for the UK and to make quicker progress with new partners' (UK Government 2017, pp. 55-56). Yet any WTO member might object and demand to negotiate with the UK, including about disentangling the EU's agricultural commitments. As a priority, the UK needs to clarify its trade relations with the EU and in the WTO before it can negotiate any 
trade agreements with other countries. Holmes et al. (2016, p. 22) argue that 'the workload and time pressure that even a least-change version of Brexit entails suggest that deciding, let alone negotiating, a completely new regime is unrealistic' in the next few years. Should the current global trade regime shift back towards more power-based relations, regaining trade policy autonomy may make the future trade policy of the UK as a 'middle power' more cumbersome than expected (Trommer 2017).

Second, regarding the free movement of persons, the UK government aims to ensure it can control and reduce immigration to Britain from Europe but still 'encourage the brightest and the best to come to this country' (UK Government 2017, p. 26). The status of EU citizens in the UK and of UK citizens in the EU should be secured and the Common Travel Area (CTA) with the Republic of Ireland maintained. In particular, the border between Northern Ireland and Ireland should remain open-although it will become the external border of the EU-and the CTA should continue to allow for free travel without passport controls. This is also imperative in the context of the 1998 Belfast (Good Friday) Agreement which had settled the conflict in Northern Ireland.

Third, most important for many voters was probably the desire to repatriate from the EU the power to make rules. Parliamentary sovereignty is a fundamental principle of the UK's unwritten constitution. The UK government proposed to repeal the 1972 European Communities Act by the 'European Union (Withdrawal) Bill' and convert the current acquis (including directly applicable regulations) into British law, which can then be changed. According to the Prime Minister, this means 'we will take back control of our laws and bring an end to the jurisdiction of the European Court of Justice in Britain' (May 2017a). Taking back control also entails that future 'laws will be made in London, Edinburgh, Cardiff and Belfast, and will be based on the specific interests and values of the UK' (UK Government 2017, p. 13).

In light of these British preferences, which lessons can be learned for each of them from EFTA's experience?

\section{EFTA Lessons for Trade in Goods and Services}

The EEA Agreement has, since 1994, extended the internal market's four freedoms as well as co-operation in horizontal and flanking policies (such as research and development, environment, or consumer protection) to the EFTA members, except for Switzerland. In brief, these freedoms removed technical, regulatory and legal barriers between the EEA states; liberalized monopolistic public utility markets such as energy supply or telecommunication services; and harmonized or recognized equivalent rules, for instance the mutual recognition of professional qualifications, intellectual property and financial supervision. This alignment guarantees equal protection for all citizens and a level playing field for economic operators. Furthermore, with the entry into force of the Maastricht Treaty, restrictions on capital movements and payments across borders were largely prohibited (Art. 63-66 of the TFEU). Excluded from the EEA are the common agricultural and fisheries policies, the customs union and common commercial policy, taxation, the CFSP, justice and home affairs and the economic and monetary union.

EFTA itself is an intergovernmental organization establishing a free trade area. It thus has no common commercial policy or external tariff. This enables the EFTA states to pursue their own trade policy both jointly and individually. Prominent examples for this flexible approach are the FTAs that Switzerland and Iceland have concluded with China or the FTA between Switzerland and Japan, cases in which the EFTA states were not able to agree on a common approach. In addition, EFTA currently runs a worldwide network of 27 FTAs covering 38 countries (EFTA 2017). Although this third-country policy was initially established to 'emulate' the EU's trade policy, the EFTA countries sometimes conclude FTAs earlier than the EU does.

This section will show, first, that dynamic forms of external differentiated integration such as the EEA suffer from fuzzy boundaries regarding the precise scope of a third country's participation in the internal market. Moreover, the simultaneous applicability of EU rules and national rules to allow for the 'parallel marketability' of goods, for instance in devolved regions of the UK, is an unlikely solution. 


\subsection{Fuzzy Freedoms in External Differentiated Integration}

The four freedoms are, in cases of external differentiation, difficult to disentangle; and the actual scope of the EEA's internal market coverage is in most areas indistinct, as the degree of correspondence between EU and EEA law varies greatly. The free movement of goods, for instance, comprises various EU acts relying on a legal basis that refers to the (excluded) EU treaty chapter of agriculture and fisheries. Moreover, the lines between the internal market per se and other parts of EU law have become increasingly blurred. Consequently, an EU act can include both EEA-relevant provisions and non-EEA relevant provisions. This indistinctness complicates the selection and incorporation of the relevant secondary law by the EEA EFTA countries. The EEA is also affected by the (unwanted) spillover of issues that are traditionally linked to integration in 'core state powers' such as fiscal affairs, defence and foreign policy, migration, citizenship and internal security. For example, the EFTA Surveillance Authority (ESA) and the EFTA Court (2011) forced Liechtenstein to adjust its tax act which had infringed on the EEA rules governing state aid. The EEA EFTA states also had to incorporate Directive 2008/99 on the protection of the environment through criminal law or Directive 2009/43/EC on simplifying terms and conditions of transfers of defence-related products into the EEA Agreement.

In contrast to the EEA Agreement, the sectoral agreements between Switzerland and the EU do not cover the free movement of services (except for some aspects such as civil aviation and overland transport or direct insurance for damage). According to the Swiss Federal Council (2006, p. 6897), negotiations on an agreement failed because the EU insisted on the incorporation of horizontal policies like competition, state aid or company law. Moreover, Switzerland was not willing to liberalize its state-controlled sectors such as telecommunications, electricity or postal services at the speed and to the extent required by EU law. The Swiss government also faced domestic opposition towards the incorporation of EU acts combatting money-laundering or insider-trading (Nufer 2006, p. 11).

However, the lack of an agreement governing the free movement of services increasingly impedes market access for Swiss businesses. The Swiss Bankers Association (2017) thus favours, in the longer run, a new sectoral agreement on at least financial services with the EU. The Swiss banks are-as is London's finance industry, in view of Brexit-particularly interested in the so-called EU passport system, which allows banks or financial companies that are authorized to do business in their home country to trade across the entire EU without separate authorization in the other member states. However, passporting rights are only available if an agreement ensures the literal and dynamic adoption of the relevant EU acquis. The EEA EFTA states are currently the only non-EU countries to which such passporting rights were granted. By contrast, Switzerland has to ask for an equivalence treatment which is much more of a 'piecemeal approach' because the rights granted by equivalence mostly cover specific parts of an EU act and can be withdrawn by the Commission at any time (European Parliament 2017, p. 2).

In this regard, the principle of 'parallel marketability' of goods in Liechtenstein has attracted some attention in the UK, especially in the devolved regions that voted against Brexit.

\section{2. 'Parallel Marketability' as a Solution?}

Frommelt (2017) shows that there are various opt-outs and tailor-made arrangements for the EEA EFTA states and, not surprisingly, in particular for Liechtenstein, which is by far the smallest EEA member. By the end of 2015, 42\% of the EU law in force in the EEA did not fully apply to Liechtenstein. By contrast, Iceland had opt-outs in place for $7.8 \%$ of the EU acts in force and Norway for $1.6 \%$. Most of Liechtenstein's specific opt-outs are technical exemptions that are related to its small size or its close relations with Switzerland (Frommelt 2016). Two tailor-made arrangements for Liechtenstein are of particular interest in the Brexit debate: its 'special solution' for the free movement of persons (see below) and the principle of parallel marketability.

When in December 1992 the Swiss people and cantons rejected EEA membership, whereas the citizens of Liechtenstein approved it one week later, the maintenance of the much appreciated customs union and open border between the two neighbouring countries posed a challenge. To allow 
Liechtenstein to join the EEA, innovative adaptations of several bilateral Switzerland-Liechtenstein agreements were necessary. This 'squaring of the circle' was rendered possible by the political will on all sides in view of the democratic votes, the tiny territory of the principality, and the fact that Art. 121(b) of the EEA Agreement had already recognized in the regional union between Switzerland and Liechtenstein (see Gstöhl 1997). A reintroduction of border controls would have been contrary to the very idea of European integration. Part of the solution was the 'parallel marketability' of goods that enables Liechtenstein to apply Swiss technical regulations and standards deriving from its regional union with Switzerland on its own market in parallel with the legislation implementing the EU acts incorporated into the EEA Agreement. Liechtenstein had to create a national market surveillance and control system in order to prevent Swiss products that differ from EEA standards being exported into EEA countries and products following different EEA standards being marketed in Switzerland.

The parallel marketability mainly covers goods with different tariffs (such as fish or agricultural products) as well as products with different technical standards (like chemicals or medicinal products). Due to the various sectoral agreements between Switzerland and the EU, the number of products subject to parallel marketability has decreased significantly over time. Overall, the system has worked well, but it also has its limits. For example, a judgement of the ECJ (2005) related to the calculation of the term of protection of specific certificates for medicinal products approved by Switzerland, and thus also by Liechtenstein, has forced both countries to restrict the parallel marketability in order to protect the economic interests of Swiss business (Frommelt and Gstöhl 2011, p. 43).

The Scottish Government (2016, p. 35) argues that the "principle of "parallel marketability" whereby goods and services originating in Scotland may be legally marketed in both the UK and the EEA' could in future ensure Scotland's simultaneous membership in the EU internal market and the UK customs union. However, despite the success of parallel marketability in Liechtenstein, the functioning of such a model in Scotland or Northern Ireland is highly questionable as their respective territories are much bigger than Liechtenstein. Furthermore, it would require that the EU and the UK formally agree on some kind of harmonization of technical barriers to trade in order to keep the number of products with different standards as low as possible. Put simply, due to the different political context and its small size, Liechtenstein can hardly be treated as a viable precedent.

Altogether, there are numerous EFTA lessons for trade in goods and services. First, as a free trade area and intergovernmental organization, EFTA allows its members to conduct an own trade policy vis-à-vis third countries, but also offers the advantage of negotiating together in case of common interests. Second, all EFTA states considered a traditional FTA with the EU insufficient, and they were willing to adapt their national law to EU rules by concluding agreements with the EU to ensure further access to the internal market. Moreover, the practice of 'autonomous adaptation' to EU rules in Switzerland shows that, due to its high economic interdependence with the EU, the alignment of rules goes de facto beyond formal agreements. This raises the question as to what extent and how the post-Brexit UK would be ready to avoid divergence between national and EU law. Third, the regulatory boundary of the EFTA states' relations with the EU is difficult to draw as the scope of their external differentiated integration is diffuse. Fourth, the principle of homogeneity, as stated in the EEA Agreement, indeed guarantees non-member states non-discriminatory access to the EU internal market. Due to the often low speed of incorporation in the EEA, however, market homogeneity is not always achieved. Subsequently, the EEA EFTA states may temporarily be impeded from access to the EU internal market. Fifth, Liechtenstein is, due to its small size, the only EFTA state that has been able to acquire a substantial number of opt-outs and tailor-made arrangements, such as the principle of parallel marketability.

The second particularity of Liechtenstein's EEA membership, which has drawn some interest in the UK, is its 'special solution' for the free movement of persons (see Section 5.2 below). 


\section{EFTA Lessons for the Free Movement of Persons}

One of the most salient issues in the Brexit debate has been the free movement of persons. The UK government aims to ensure it can control and reduce immigration from Europe. This section highlights the importance that the EU attaches to the principles of non-discrimination and of a balance of benefits and obligations. It then examines whether Liechtenstein's 'special solution' for the free movement of persons can serve as a precedent for the UK.

\subsection{Non-Discrimination as a Core Principle}

The free movement of persons gives EEA nationals the possibility to live, work, establish businesses and study in any EEA state. To this end, members shall eliminate any discrimination on the grounds of nationality as well as 'non-discriminatory measures which are liable to prohibit, impede or render less advantageous the use of the freedoms' (Fredriksen 2016, p. 404).

Switzerland concluded in 1999 an agreement on the free movement of persons (AFMP) in the framework of the first package of bilateral agreements with the EU. It contained a 'guillotine clause', a contractual stipulation that links all treaties. If only one of them were not ratified, or cancelled later, all of the agreements would be deemed terminated. The AFMP has from the start faced some domestic opposition, and since 2000 four popular votes related to the agreement have taken place. A majority of the Swiss people and cantons supported the first package of bilateral agreements as well as the extension of the AFMP to the new EU member states in 2005 and 2009. However, in 2014 a popular initiative requiring the introduction of immigration quotas was accepted by a slim margin of 50.3\% (Swiss Federal Council 2017). This constitutional amendment, which the Swiss government had to implement within three years, was not compatible with the agreement. The non-extension of the AFMP to Croatia after its accession to the EU in 2013 triggered Switzerland's (partial) loss of access to the EU's 'Horizon 2020' and 'Erasmus+' programmes. The Commission rejected the Swiss proposal of a unilateral safeguard clause with a national ceiling on EU migration to Switzerland as a solution, while the 'guillotine clause' risked terminating the entire series of bilateral treaties. Finally, in December 2016 the Swiss Parliament adopted a more flexible and much weaker implementation which does not include quotas or any kind of discrimination on the grounds of nationality and can thus be considered compatible with the AFMP. The negotiations were complicated by the Brexit debate, as the EU was 'wary of creating a flexible precedent that Britain might be able to use in negotiating a new bilateral relationship with the bloc' (The Guardian 2016).

The experience with the EEA and the sectoral agreements of Switzerland show the fundamental character of the principle of non-discrimination on the grounds of nationality. Likewise, it highlights the indivisibility of certain aspects of the EU internal market in order to maintain a balance between benefits and obligations. In EFTA history, this is known as one of the so-called 'Interlaken principles' that the EU had stressed since the late 1980s (see De Clercq 1987). The EU does not grant any à la carte integration with its internal market in terms of picking and choosing. Indeed, rich countries such as the EFTA states contribute as well to cohesion in the EU through special financial co-operation mechanisms. Moreover, the EU has, in return for internal market access, also sought additional bilateral agreements in areas of its own interest such as taxation. This also means that a comprehensive participation in the internal market without free movement of persons is hard to imagine. The Council of the EU (2017, para. 7) recently reiterated vis-à-vis Switzerland 'that the free movement of persons is a fundamental pillar of EU policy and that the internal market and its four freedoms are indivisible'.

Despite constituting an essential part of the EEA and Switzerland-EU relations, the scope of free movement of persons differs between the two models of association, but also compared to the EU (see Tobler 2016). This becomes particularly visible in relation to the Citizenship Directive 2004/38/EC. After long negotiations and after the EU invoked Art. 102 of the EEA Agreement, which stipulates that the parts of the Annex of the EEA Agreement directly affected by the EU act in question are suspended if a conciliation procedure is unsuccessful, the EEA EFTA states in 2007 finally agreed to incorporate this directive. However, Decision No 158/2007 of the EEA Joint Committee included some specific 
adaptations as well as a Joint Declaration by the contracting parties. This Joint Declaration states, for instance, that the concept of Union citizenship has no equivalent in the EEA Agreement, and thus excludes any prejudice to the evaluation of the EEA relevance of future EU legislation as well as future case law of the ECJ based on the concept of Union citizenship. The exact demarcation of the free movement of persons in the EEA remains uncertain. According to Fredriksen (2016, p. 400), the EFTA Court has so far done 'its utmost to preserve homogeneity in the interpretation and application' of the Citizenship Directive. In contrast to the EEA EFTA states, Switzerland has successfully resisted EU pressure to adjust the AFMP to the Citizenship Directive. Hence, Switzerland is not obliged to follow the ECJ's rulings based on the concept of Union citizenship (Tobler 2016, p. 5). This affects, in particular, the rights of economically inactive EU nationals (for instance, with regard to social assistance) as well as the practice of family reunification in Switzerland. Another challenge for EFTA states is the growing political connection between the free movement of persons and EU migration policy. For instance, in its review of the EEA Agreement, the European Commission $(2012$, p. 4) stated that it 'would be important as well to include the [EU] policy on trafficking in human beings in the EEA Agreement'.

In the updated EFTA Convention, which entered into force in 2002 in parallel with the EU-Swiss bilateral agreements, free movement of persons (as well as trade in services and other issues) was also granted among the four EFTA states themselves.

The most prominent and politically sensitive opt-out of Liechtenstein is the 'special solution', which allows a quantitative restriction on the number of new residents. This arrangement was the outcome of a long process.

\subsection{Liechtenstein's 'Special Solution' in the EEA: A Precedent?}

The EEA Agreement contained in Protocol 15 a standard transitional period (until the end of 1997) and a review clause which foresaw the joint review of transitional measures 'duly taking into account the specific geographic situation of Liechtenstein'. In the context of the negotiations adapting the EEA Agreement to the revised Liechtenstein-Switzerland regional union, the Liechtenstein government obtained in 1995 an additional joint declaration with the EEA Council (Decision 1/95). This declaration recognized Liechtenstein as a very small area of rural character with an unusually high percentage of non-national residents and employees. It also acknowledged the principality's vital interest in maintaining its own national identity.

In view of the expiry of the transitional period as of 1998 and the failure to negotiate a solution on time, the Liechtenstein government invoked the safeguard clause of the EEA Agreement (Art. 112) which allows a contracting party to take unilateral measures 'if serious economic, societal or environmental difficulties of a sectorial or regional nature liable to persist are arising'. In 1999, the EEA Joint Committee agreed in Decision 191/1999, under Liechtenstein's chair, to extend the transitional period until the end of 2006 because the principality's situation still justified the maintenance of special conditions. The special solution was incorporated as a 'sectoral adaptation' to Annexes V (free movement of workers) and VIII (right of establishment) of the EEA Agreement and, therefore, did not require specific ratification by the contracting parties. Before the expiry of that second transitional period, the EU had to enter negotiations with the EEA EFTA countries on the enlargement of the EEA to the 10 new EU member states (Art. 128 of the EEA Agreement). On this occasion, the special solution for Liechtenstein was slightly amended in 2004. It no longer expired automatically, but became a 'quasi-permanent' exception, subject to a review every five years. The later EEA enlargement agreements (Bulgaria, Romania, Croatia) followed this example without changing the quota.

As a result, the free movement of persons applies to Liechtenstein citizens, but EEA citizens wishing to live in Liechtenstein have to obtain a residence permit. The number of permits is limited, with a yearly net increase. There are no restrictions preventing family members of holders of a residence permit from joining them, and they also have the right to take up economic activity. The authorities shall grant the new permits in a way that is not discriminatory and does not distort competition. In order to guarantee equal chances, half of them are granted by a ballot procedure. The number of 
applications for residence permits exceeds the allocable quota by multiple times. Yet, obtaining a residence permit is not a requirement to work in Liechtenstein, and many people commute on a daily basis from neighbouring countries.

Liechtenstein's special solution is closely linked to its tiny territory $\left(160 \mathrm{~km}^{2}\right)$ and the high number of foreigners in its resident population of 38,000 (about one third and two thirds of the workforce, respectively). It has emerged over time as a complex, tailor-made solution institutionally embedded in the EEA. No EU or EEA EFTA state has so far contested Liechtenstein's limited absorption capacity (European Commission 2015). This is also in line with the declaration on Art. 8 of the TEU, introduced by the Lisbon Treaty, in which the EU promises to 'take into account the particular situation of small-sized countries which maintain specific relations of proximity with it'. This declaration is obviously not applicable to the UK.

The lessons to be drawn from EFTA's participation in the free movement of persons are, first and foremost, the importance of safeguarding non-discrimination and the role this free movement plays as part of a balance of benefits and obligations. This means that comprehensive participation in the internal market without free movement of persons is hard to imagine for countries such as the EFTA members or the UK. Comprehensive market access also implies, in turn, that a financial contribution to reduce economic and social disparities in the EU is expected which is 'proportionate to the substantial benefits' that a country draws from its participation in the internal market (Council of the EU 2017, para. 7). Second, the actual scope of the free movement of persons may differ slightly between the EU and a case of external differentiation, but still includes issues such as the free movement of workers, students and economically inactive persons, the freedom of establishment, family reunification, or the coordination of social security systems. Third, the special arrangement for Liechtenstein in this field (which is neither an opt-out nor a suspension) is closely linked to its small territory and unusually high share of foreigners. The fact that Liechtenstein was embedded in a multilateral institutional framework was conducive to a tailor-made solution and could hardly have been negotiated bilaterally.

\section{EFTA Lessons for the Institutional Structure}

The EEA is an elaborate two-pillar system, whereas Switzerland's bilateral relations with the EU are largely based on agreement-specific joint committees. Both cases show that far-reaching participation in the internal market poses important institutional challenges (see also Gstöhl 2015). This section introduces the role that decision-shaping plays for a homogenous EEA market and Switzerland's search for an adequate institutional framework with the EU. It then discusses whether and how the UK could become an EEA EFTA state or simply an (associate) member of EFTA.

\subsection{Two-Pillar System in the EEA: Decision-Shaping in Return for Market Homogeneity}

The EEA negotiations launched in 1989 between the then 12 EU member states and seven EFTA countries were difficult when it came to institutional questions (see Gstöhl 1994). In December 1991, the ECJ delivered its Opinion 1/91 according to which the proposed new joint EEA Court, composed of judges from the ECJ and the EFTA side, but functionally integrated with the ECJ, was incompatible with EU law (ECJ 1991). In order to avoid the risk of undermining the autonomy of the Community legal order by infringing on the jurisdiction of the ECJ, the EFTA countries ultimately accepted that they would have to create their own EFTA Court of Justice. The EEA Joint Committee was tasked with reviewing the development of case law and settling any disputes between the two Courts. The institutional set-up of the EEA can best be described as a two-pillar system with the EEA EFTA institutions, matching those on the EU side for decision-making as well as the supervision and judicial control of EEA law.

The 'dilemma' of the EEA EFTA states consists in the fact that they do not have the right to vote in EU policy-making and are unable, constitutionally, to accept decisions made by the EU institutions directly. Despite their objection to the transfer of legislative and judicial power to the EU, the actual level of centralization in the EEA transcends the narrow confines of its initial conceptualization as an 
agreement subject to public international law. Against this background, the EFTA Court (1998) has interpreted the EEA Agreement as an 'international agreement sui generis with a distinct legal order of its own' that is closer to supranational EU law than to public international law. Indeed, over the last two decades, the EEA's two-pillar structure has been filled with a multitude of ad hoc rules for EEA decision-making that alternate between intergovernmental co-operation within the EEA Joint Committee (for instance for the flanking policies) and the EEA EFTA states' subordination to the EU pillar with exclusive decision-making by EU bodies (like EEA EFTA participation in the European Aviation Safety Agency).

The deepening of the EEA's institutionalization takes place along two lines. First, there is a certain transfer of decision-making power from the EEA EFTA states to the relevant EFTA and EU bodies. Second, there is an institutional spillover of EU-specific patterns of governance, for instance, through the increasing importance of EU agencies for EEA-relevant policies, which ties EEA decision-making more closely to that of the EU. This deepening mostly occurs during the incorporation of EU legal acts, since the main parts of the EEA Agreement have remained largely unchanged since 1994.

The degree of the EEA EFTA states' organizational inclusion in EU policy-making ranges widely from no to almost full inclusion (in EU committees that do not have legislative power). There are various types and mechanisms of decision-shaping, such as the submission of written comments, the secondment of national experts, and the participation in expert groups of the Commission or in comitology committees. Nonetheless, the incorporation of EU secondary law into the EEA Agreement is determined by an 'inherently asymmetric process' (EFTA Secretariat 2009, p. 7). The most prominent examples of institutional asymmetry are: the lack of a right to vote in the above-mentioned committees and expert groups; and the fact that access to the European Parliament and the Council of the EU was refused. There are informal ways to exchange views and information between the EEA EFTA states and the EU. For instance, the EEA EFTA states are regularly invited to participate in the Council's informal meetings, which are organized by the presidency of the Council of the EU. However, this is mainly seen as a way to gather information rather than to exert political influence (Norwegian EEA Review Committee 2012, Chapter 9). Moreover, reports from experts of the EEA EFTA states participating in expert groups of the Commission or in comitology committees show that they may in practice face further restrictions, for instance, limited or late access to documents (Jónsdóttir 2013).

Furthermore, Norway and Iceland have been associated with the Schengen area and Dublin Convention since 2000, and Switzerland and Liechtenstein since 2008 and 2011, respectively. These associations are located outside the EEA on a bilateral level. The EFTA countries are required to adopt the relevant acquis. In return, similar to the EEA, they have the right to participate in decision-shaping, but not a formal right of decision-making in the further development of the acquis in this field.

For forms of external differentiation such as the EEA, which extend the internal market based on the acquis, the common rules must be identical in substance, making homogeneity a key principle. The common rules are continuously updated by adding new EEA-relevant EU legislation. At the same time, the institutions of the EU and of the EFTA pillar ensure the supervision and identical interpretation of those rules. In practice, homogeneity means that the contracting parties have to select EEA-relevant EU acts from EU secondary law, and ensure the timely and complete incorporation of those EU acts into the EEA Agreement as well as their correct transposition and application within the national legal orders.

Assessments of the EEA's functioning during the past two decades have overall been positive (Council of the EU 2016; European Commission 2012; Norwegian EEA Review Committee 2012). However, the EEA is plagued by various shortcomings, in particular a slow speed of incorporation of new EU secondary law into the EEA Agreement (Frommelt 2017). Taking into account the dynamics of EU law-making and the complexity of the EEA policy process, delays are often unavoidable. This means that the EEA EFTA states may have to comply much later with an EEA-relevant EU 
act than EU members. Hence, different sets of rules apply for the EU and EEA EFTA states, which temporarily reduces the market's homogeneity. In total, only $16 \%$ of the 4573 directives and regulations incorporated into the EEA Agreement between 1994 and 2015 had the same compliance dates for the EU and the EEA EFTA states (Frommelt 2017). Put differently, the EEA EFTA states could not ensure homogeneity for the entire period of application of EU acts in $84 \%$ of cases. In practice, different compliance dates can have two opposite effects, depending on the legal act. On the one hand, stakeholders may face different legal requirements when operating in the EU or the EEA EFTA states, which can lead to competitive advantages for operators based in the latter. On the other hand, the citizens and businesses of the EEA EFTA states and the products originating in those countries may not be able to benefit right away from the internal market. Both effects infringe on the homogeneity and legal certainty in the EEA but, in practice, are often neglected due to the small size of the EEA EFTA states.

Frommelt (2017) argues that institutional, country-specific and policy-related factors define the conditions of well-functioning external differentiated integration. That is, the institutional set-up of external differentiation is a necessary but not sufficient condition of effectiveness. In this regard, the specific characteristics of the EEA EFTA states, in particular the combination of their small size, strong economic interdependence with the EU and high state capacity, are likely to mitigate constraints resulting from the institutional complexity of the EEA's two-pillar structure. Yet, over the last two decades, the speed of incorporation has differed greatly across EU acts, which shows that the effectiveness of the EEA is also determined by the specific policy-related features of the legal acts in question, such as its institutional requirements, functional scope, or salience.

In 2014, due to the ongoing concerns about the backlog of EU legal acts which have not yet entered into force in the EEA, the EEA EFTA states streamlined the procedures for incorporating EU acts into the EEA Agreement (EFTA Secretariat 2016). Indeed, based on preliminary data, Frommelt (2017) shows promising results of those efforts to increase the EEA's speed of incorporation. However, this only applies to EU acts that, by their nature, (i) do not have a material and/or structural impact on EEA law or the EEA institutional framework; (ii) do not need any EEA-specific adaptations; and (iii) do not call for ratification by the national parliaments of the EEA EFTA states. All other EU acts still have to go through a time-consuming assessment in order to ensure their compatibility with the EEA's two-pillar structure and its functional scope.

The EFTA states are highly developed, small and 'like-minded' countries that are, in principle, eligible for EU membership. They have to 'speak with one voice' in the EEA bodies. If an EEA EFTA state opposes the incorporation of a new EU act-for instance, due to a misfit with its economic preferences or due to constitutional constraints-this could trigger the suspension of the affected parts of the EEA Agreement for all EEA EFTA states. It is, therefore, no surprise that the EEA EFTA states are not very keen on having more members, and in particular a large member such as the UK.

\subsection{Switzerland's Search for an Institutional Solution}

EFTA member Switzerland opted, through a referendum in 1992, not to participate in the EEA. Instead, the country pursued a bilateral approach, building on its 1972 FTA with the EC. In two package deals in 1999 and 2004, it concluded 16 new sectoral agreements with the EU (free movement of persons, technical barriers to trade, public procurement, civil aviation, overland transport, agriculture, research, Schengen and Dublin association, taxation of savings, fight against fraud, processed agricultural products, environment, statistics, media, education, and pensions). A few more agreements have followed since and some are still under negotiation. Most of these 'bilaterals' are based on the notion of equivalence of laws between the EU and Switzerland, and any changes need to be negotiated, albeit with the exceptions of civil aviation and the Schengen/Dublin association. This sectoral approach lacks an overarching structure to deal with the approximately 20 main agreements, most of which at a technical level are run by a consensus-based Joint Committee, and the more than 100 secondary agreements. 
The EU has, in recent years, insisted on the limits of such a static and selective approach and on finding a more efficient institutional solution for taking over relevant new EU acts and their interpretation. In 2010, the Council of the EU (2010, para. 42) concluded that '[d]ue to a lack of efficient arrangements for the take-over of new EU acquis including ECJ case-law, and for ensuring the supervision and enforcement of the existing agreements, this approach does not ensure the necessary homogeneity in the parts of the internal market and of the EU policies in which Switzerland participates'. In response, the Swiss Federal Council (2012) submitted a number of institutional proposals to the EU, accepting the overall objective of homogeneity and the incorporation of future changes to the acquis, provided that this was not automatic and that Switzerland could in turn participate in the decision-shaping process. However, the EU did not approve the proposed two-pillar model, whereby each party would retain responsibility for ensuring the application and interpretation of the common rules on its own territory (Barroso 2012). In other words, Swiss national surveillance was excluded. Instead, the new 'institutional framework should present a level of legal certainty and independence equivalent to the mechanisms created under the EEA Agreement' (Council of the EU 2012, para. 33).

In 2013, it was agreed as a basis for negotiation that the ECJ should interpret the EU acquis adopted by Switzerland to strengthen legal certainty (Rossier and O'Sullivan 2013). Yet, the talks were temporarily stalled as a result of the Swiss acceptance in 2014 of an initiative requiring the introduction of immigration quotas (see above). Negotiations on an institutional framework agreement were resumed in 2017 (Council of the EU 2017).

The last section looks into the conditions and implications of the UK joining EFTA, and possibly also the EEA, before summarizing the main institutional lessons.

\subsection{UK Membership of EFTA, the EEA or Association with EFTA?}

Art. 128 of the EEA Agreement stipulates that any European state joining the EU shall, and the Swiss Confederation or any European state becoming a member of EFTA may, apply to become a party. Hence, the UK—currently part of the EEA via its EU membership—-would have to adhere to EFTA after Brexit in order to rejoin the EEA. Direct accession to the EEA is not foreseen in view of the EEA's two-pillar structure (Baur 2016, p. 60). The criteria for EFTA membership are not straightforward, and there is no specific accession procedure besides negotiations with the EFTA Council, which decides by unanimity.

According to Art. 56 of the EFTA Convention, only (European) states may join, and they are expected to become a party to EFTA's FTAs as well. Strictly speaking, this would exclude an application from Scotland or Northern Ireland. The Preamble of the EFTA Convention refers to proximity, longstanding common values and European identity, and WTO membership. Baur (2016, pp. 63-64) argues that, by analogy, the EU's 'Copenhagen criteria' could serve as guidance for EFTA accession, which the UK would obviously fulfil. Whether British EFTA membership would be politically feasible is not to be taken for granted, though. Not all EFTA states have unconditionally welcomed the idea, since the UK would be a very dominant (and potentially difficult) partner. As an EFTA country in the EEA, the UK would have to speak 'with one voice' to the EU together with three small states, and it would replace the jurisdiction of the ECJ by the jurisdiction of the EFTA Court and the surveillance of the Commission by that of the ESA. Compared to the UK's votes and seats in EU institutions today, the EEA offers very little participation in EU decision-making yet entails similarly extensive internal market obligations. It should be kept in mind that one of the major reasons for Switzerland's rejection of EEA membership and for Austria, Finland and Sweden to join the EU in 1995 were the institutional shortcomings of the EEA (see Gstöhl 1994).

If the UK would, instead, follow the 'Swiss model' and, permanently or temporarily, join EFTA but remain outside the 'quasi-supranational' EEA, it could establish free trade with the four EFTA countries and negotiate to join the Association's existing FTAs, thereby possibly speeding up the 
creation of its own free trade regime. The UK's free movement of persons would be restricted to the small EFTA countries.

Alternatively, a mere association with EFTA, 'embodying such reciprocal rights and obligations, common actions and special procedures as may be appropriate', might be possible as well (Art. 56(2) of the EFTA Convention). The only associated member so far has been Finland between 1961 and 1986, as a result of its special relations with the Soviet Union during the Cold War. The so-called FINEFTA association gave Finland quasi-membership status because a few years into the association's existence the EFTA Council and the FINEFTA Joint Council held simultaneous meetings (Kinnas 1979, pp. 53-56). Whether such 'second-class' membership in the form of a 'UKEFTA' would be politically feasible and desirable remains an open question (see Phinnemore and Najy 2017).

Despite the fact that the UK will not have to seek increasing convergence with EU law but rather prevent growing divergence, there are various EFTA lessons for the institutional architecture of the UK's future relationship with the EU. First, the 'Interlaken principles' which the EU set out in the late 1980s are still valid (De Clercq 1987): 'the EU first', meaning priority has to be given to the EU's internal integration and the preservation of its decision-making autonomy. For the EFTA countries, this implies that they have to be very active in the decision-shaping process, which is, however, rather a way of gathering information than exerting political influence. Second, the EU is afraid of setting any precedents by giving a non-member state specific rights that could then trigger more demands from others. Third, any close economic association with the EU based on its acquis requires a satisfactory mechanism through which the third countries keep up with the evolution of the acquis in order to safeguard market homogeneity. There is an inherent trade-off between the benefits resulting from the internal market and the lack of participation in the law-making process, which also leaves little room for parliamentary control. Fourth, even in the very institutionalized EEA (or 'Norwegian model'), the EFTA institutions and the joint EEA bodies are not sufficient to ensure an entirely homogeneous market. How effective external differentiation is varies across policy areas, since country-specific and policy-related factors play a role for compliance. Fifth, the EEA would provide the UK with its own trade policy, yet still require full free movement of persons and the jurisdiction of the EFTA Court. Sixth, the bilateral sectoral approach (or 'Swiss model') also has its institutional limits: no solely national surveillance or enforcement mechanisms for the interpretation of EU law-based rules appear to be acceptable to the EU. Tellingly, in the case of the ongoing association negotiations of the three small-sized European countries Andorra, San Marino and Monaco, the European Commission (2013, p. 6) considered that some of these tasks could be carried out directly by itself and the ECJ.

Finally, membership restricted to EFTA only-either full or via an association-would meet all three British 'red lines', but offer no internal market access in the EU, only among the fellow EFTA countries. In this economically less interesting case, the UK would still have to negotiate its future relationship with the EU in the form of an FTA. Moreover, the negotiation of other bilateral trade agreements beyond Europe will take time, even if the UK were to benefit from faster access to the already existing EFTA FTAs with third countries.

\section{Conclusions: 'Global Britain' in Europe}

In light of the ambiguity surrounding the ongoing Brexit negotiations and in particular the UK's position on its future relationship with the EU, this article has attempted to derive relevant lessons from the EFTA countries' experience with the internal market. It examined whether and under which conditions the UK could go 'back to the future' and (re-)join EFTA and/or the EEA. While specific lessons of external differentiated integration have been set out in each section, it is safe to conclude that, overall, 'having the cake and eating it too' in the form of a far-reaching participation à la carte in the internal market, which would, for instance, exclude the free movement of persons, is not on offer. If the UK were to insist on its three 'red lines' (that is, its own trade policy, no free movement of persons, and taking back legal control), a 'hard' Brexit in the form of a limited, FTA-based model would be the logical result. 
While there is some flexibility in how third countries can be associated with the internal market, the EU insists on a balance of benefits and obligations. This does not mean that all four freedoms will have to be accepted; it all depends on the ambitions. While Turkey is in a customs union with the EU which is currently limited to trade in certain goods, Canada has signed a comprehensive agreement on trade in goods and services, while Switzerland's relations cover goods and persons, and the EEA Agreement covers all four freedoms of the internal market. Hence, there are various ways for the UK to shape its future trade ties with the EU. The main lesson to be learned from EFTA's differentiated integration is that an FTA alone is unlikely to satisfy the needs and demands of business and people. In the words of Prime Minister May, 'a Canadian-style free trade agreement [ ... would] represent such a restriction on our mutual market access that it would benefit neither of our economies' (May 2017c). On the other hand, 'European Economic Area membership would mean the UK having to adopt at home-automatically and in their entirety-new EU rules [ ... ] over which, in future, we will have little influence and no vote' (May 2017c). Moreover, the various future partnership papers recently published by the UK suggest that, for issues such as customs or data protection, the UK intends to operate a regime that aligns closely with the respective EU acquis (Department for Exiting the European Union 2017a). However, the papers still lack details about the institutional framework of such an alignment. At the same time, the paper about enforcement and dispute resolution lacks any commitment to include a specific model (Department for Exiting the European Union 2017b).

Over the past 25 years, all EFTA states have steadily extended and deepened their relationship with the EU in order to secure access to substantial parts of the internal market based on an alignment with EU rules. Such deep and comprehensive integration requires an efficient institutional set-up for taking over relevant new EU acts and for ensuring the surveillance and enforcement of these obligations. An internal market association will unavoidably come with rather limited participation in EU policy-making. Moreover, the regulatory boundary of external differentiation is difficult to draw, and spillover from other-in principle, excluded-parts of the EU acquis are more likely, the more ambitious the economic partnership. Hence, 'Global Britain' (May 2017a) might free itself from the 'control' of Brussels, but it still has to find its new place in Europe, and this place is unlikely to be reached by going 'back to the future'.

Author Contributions: Sieglinde Gstöhl and Christian Frommelt conceived and co-wrote the article; Christian Frommelt collected and analyzed the data referred to as (Frommelt 2017).

Conflicts of Interest: The authors declare no conflict of interest.

\section{References and Notes}

Barroso, José Miguel. 2012. Lettre de la Commission de l'UE à la Suisse. December 21. Available online: https:/ /www.eda.admin.ch/content/dam/dea/de/documents/eu/Brief-BXL-CH-20121221_de.pdf (accessed on 1 October 2017).

Baur, Georges. 2016. Who Can Join the European Economic Area. In The European Neighbourhood Policy in a Comparative Perspective: Models, Challenges, Lessons. Edited by Sieglinde Gstöhl. Abingdon: Routledge, pp. 55-71.

Burke, Ciarán, Ólafur Ísberg Hannesson, and Kristin Bangsund. 2016. Life on the Edge: EFTA and the EEA as a Future for the UK in Europe. European Public Law 22: 69-96.

Council of the EU. 2010. Council Conclusions on EU Relations with EFTA Countries. 3060th General Affairs Council Meeting. Brussels, December 14. Available online: https:/ / eeas.europa.eu/sites/eeas/files/council_ iceland.pdf (accessed on 1 October 2017).

Council of the EU. 2012. Council Conclusions on EU Relations with EFTA Countries. 3213th Transport, Telecommunications and Energy Council Meeting. Brussels, December 20. Available online: http:/ / eeas.europa.eu/archives/docs/norway/docs/2012_final_conclusions_en.pdf (accessed on 1 October 2017). 
Council of the EU. 2016. Council Conclusions on a Homogeneous Extended Single Market and EU Relations with Non-EU Western European Countries. Press Release 776/16. December 13. Available online: http:/ / www.consilium.europa.eu/press-releases-pdf/2016/12/47244652378_en.pdf (accessed on 1 October 2017).

Council of the EU. 2017. Council Conclusions on EU Relations with the Swiss Confederation. Press Release 93/17. February 28. Available online: http:/ / www.consilium.europa.eu/press-releases-pdf/2017/2/47244655317_ en.pdf (accessed on 1 October 2017).

De Clercq, Willy. 1987. Speech at the EC-EFTA Ministerial Meeting. Interlaken, May 20. Available online: http:/ / europa.eu/rapid/press-release_SPEECH-87-32_en.htm (accessed on 1 October 2017).

Department for Exiting the European Union. 2017a. Article 50 and Negotiations with the EU; September 18. Available online: https:/ / www.gov.uk/government/collections/article-50-and-negotiations-with-the-eu (accessed on 1 October 2017).

Department for Exiting the European Union. 2017b. Enforcement and Dispute Resolution-A Future Partnership Paper. August 23. Available online: https://www.gov.uk/government/publications/enforcement-anddispute-resolution-a-future-partnership-paper (accessed on 1 October 2017).

Doherty, Brian, Christopher McCrudden, Lee McGowan, David Phinnemore, Dagmar Schiek, and John Temple Lang. 2017. Northern Ireland and Brexit: The European Economic Area Option. Brussels: European Policy Centre.

ECJ (European Court of Justice). 1991. Opinion 1/91, European Economic Area I, ECR [1991], I-6079. December 14.

ECJ (European Court of Justice). 2005. Millennium Pharmaceuticals—Novartis and Others, Joined Cases C-207/03 and C-252/03, ECR 2005 I-03209. April 21.

EFTA. 2017. Free Trade Agreements and Trade Relations by Country. Available online: http://www.efta.int/freetrade/free-trade-agreements (accessed on 1 October 2017).

EFTA Court. 1998. Case E-9/97-Erla María Sveinbjörnsdóttir v. Iceland. December 10.

EFTA Court. 2011. Case E-04/10, E-06/10 and E-07/10-The Principality of Liechtenstein, REASSUR Aktiengesellschaft and Swisscom RE Aktiengesellschaft v EFTA Surveillance Authority. May 10.

EFTA Secretariat. 2009. Decision Shaping in the European Economic Area. EFTA Bulletin. No. 1. Available online: http:/ / www.efta.int/media/files / publications / Bulletins / eeadecisionshaping-bulletin.pdf (accessed on 1 October 2017).

EFTA Secretariat. 2016. Handbook on EEA EFTA procedures for incorporating EU acts into the EEA Agreement. EFTA Bulletin. Available online: http://www.efta.int/sites/default/files/publications/bulletins/EFTABulletin-October-2016-updated.pdf (accessed on 1 October 2017).

Emerson, Michael. 2016. Which Model for Brexit? In CEPS Special Report. No. 147; Brussels: CEPS.

European Commission. 2012. A Review of the Functioning of the European Economic Area. SWD(2012) 425 final, Brussels, December 7.

European Commission. 2013. EU Relations with the Principality of Andorra, the Principality of Monaco and the Republic of San Marino: Options for the participation in the Internal Market. COM(2013) 793 final, Brussels, November 18.

European Commission. 2015. Liechtenstein Sectoral Adaptations Review. COM(2015) 411 final, Brussels, August 28.

European Parliament. 2017. Third-Country Equivalence in EU Banking Legislation. Available online: http:/ / www.europarl.europa.eu/RegData/etudes/BRIE/2016/587369/IPOL_BRI(2016)587369_EN.pdf (accessed on 1 October 2017).

Fredriksen, Halvard Haukeland. 2016. General Prohibition of Discrimination on Grounds of Nationality. In The Handbook of EEA Law. Edited by Carl Baudenbacher. Cham: Springer, pp. 391-411.

Frommelt, Christian. 2016. Liechtenstein's Tailor-made Arrangements in the EEA: A Small State's Creative Solutions in European Integration. In State Size Matters. Edited by Sebastian Wolf. Wiesbaden: VS Springer, pp. 131-62.

Frommelt, Christian. 2017. In Search of Effective Differentiated Integration: Lessons from the European Economic Area (EEA). Ph.D. dissertation, ETH Zürich, Zürich, Switzerland.

Frommelt, Christian, and Sieglinde Gstöhl. 2011. Liechtenstein and the EEA: The Europeanization of a (Very) Small State. Rapport 18; Oslo: Utvalget for utredning av Norges avtaler med EU, Available online: http:/ / www.europautredningen.no/wp-content/uploads/2011/04/Rap18-Liechtenstein2.pdf (accessed on 1 October 2017). 
Gava, Roy, and Frédéric Varone. 2014. The EU's Footprint in Swiss Policy Change: A Quantitative Assessment of Primary and Secondary Legislation (1999-2012). Swiss Political Science Review 20: 216-22. [CrossRef]

Gstöhl, Sieglinde. 1994. EFTA and the European Economic Area or the Politics of Frustration. Cooperation and Conflict 29: 333-66. [CrossRef]

Gstöhl, Sieglinde. 1997. Successfully Squaring the Circle: Liechtenstein's Membership of the Swiss and European Economic Area. In Free Trade Agreements and Customs Unions: Experiences, Challenges and Constraints. Edited by Madeleine Hösli and Arild Saether. Brussels and Maastricht: TACIS European Commission and European Institute of Public Administration, pp. 163-76.

Gstöhl, Sieglinde. 2015. Models of External Differentiation in the EU's Neighbourhood: An Expanding Economic Community? Journal of European Public Policy 22: 854-70. [CrossRef]

Holmes, Peter, Jim Rollo, and L. Alan Winters. 2016. Negotiating the UK's post-Brexit Trade Arrangement. National Institute Economic Review 238: R22-R30. [CrossRef]

House of Commons. 2017. UK Trade Options beyond 2019: First Report of Session 2016-2017. HC817. London: International Trade Committee.

Jenni, Sabine. 2016. Switzerland's Differentiated European Integration: The Last Gallic Village? Basingstoke: Palgrave Macmillan.

Jónsdóttir, Jóhanna. 2013. Europeanization and the European Economic Area: Iceland's Participation in the EU's Policy Process. Abingdon: Routledge.

Kinnas, John N. 1979. The Politics of Association in Europe. Frankfurt: Campus Verlag.

Leuffen, Dirk, Berthold Rittberger, and Frank Schimmelfennig. 2013. Differentiated Integration: Explaining Variation in the European Union. Basingstoke: Palgrave Macmillan.

May, Theresa. 2017a. The Government's Negotiating Objectives for Exiting the EU. PM speech, London, Prime Minister's Office, Lancaster House. January 17. Available online: https://www.gov.uk/ government/speeches/the-governments-negotiating-objectives-for-exiting-the-eu-pm-speech (accessed on 1 October 2017).

May, Theresa. 2017b. Prime Minister's Letter to Donald Tusk Triggering Article 50. March 29. Available online: https://www.gov.uk/government/uploads/system/uploads/attachment_data/file/ 604079/Prime_Ministers_letter_to_European_Council_President_Donald_Tusk.pdf (accessed on 1 October 2017).

May, Theresa. 2017c. Prime Minister's Florence Speech: A New Era of Cooperation and Partnership between the UK and the EU. September 22. Available online: https://www.gov.uk/government/speeches/ pms-florence-speech-a-new-era-of-cooperation-and-partnership-between-the-uk-and-the-eu (accessed on 1 October 2017).

Norwegian EEA Review Committee. 2012. Report Submitted to the Ministry of Foreign Affairs on 17 January 2012. Utenfor og innenfor: Norges avtaler med EU, NOU 2012:2, Oslo, Norway. Available online: https:/ / www.regjeringen.no/contentassets/5d3982d042a2472eb1b20639cd8b2341/no/ pdfs /nou201220120002000dddpdfs.pdf (accessed on 1 October 2017).

Nufer, Christoph. 2006. Bilaterale Verhandlungen, wie weiter? Liberale Dienstleistungen zwischen der Schweiz und der EU: Gewinner und Verlierer aus Schweizer Sicht. Basel: Europainstitut der Universität Basel.

Pelkmans, Jacques, and Philippe Böhler. 2013. The EEA Review and Liechtenstein's Integration Strategy. Brussels: CEPS.

Phinnemore, David, and Lee McGowan. 2016. After the Referendum: Establishing the Best Outcome for Northern Ireland. Belfast: Centre for Democracy \& Peace Building.

Phinnemore, David, and Cenni Najy. 2017. The Option of Association: The United Kingdom Post-Brexit and the European Free Trade Association. Available online: http:/ / www.foraus.ch/satisfaction/downloads/249 (accessed on 1 October 2017).

Rossier, Yves, and David O'Sullivan. 2013. Eléments de discussions sur les questions institutionnelles entre l'Union européenne et la Confédération helvétique. Unpublished manuscript.

Scottish Government. 2016. Scotland's Place in Europe. Edinburgh: The Scottish Government.

Springford, John. 2017. Brexiting Swiss-Style: The Best Possible UK-EU Trade Deal. London: Centre for European Reform.

Swiss Bankers Association. 2017. Market Access. Available online: http:/ / www.swissbanking.org/en/topics/ current-issues / market-access (accessed on 1 October 2017). 
Swiss Federal Council. 2006. Europabericht 2006. June 28. Available online: https://www.admin.ch/opc/de/ federal-gazette/2006/6815.pdf (accessed on 1 October 2017).

Swiss Federal Council. 2012. Lettre de la Suisse à l’UE. June 15. Available online: https://www.eda. admin.ch/content/dam/dea/de/documents/eu/Brief-Barroso-20120615-Unterzeichnet_fr.pdf (accessed on 1 October 2017).

Swiss Federal Council. 2017. Popular Votes. Available online: https://www.eda.admin.ch/dea/en/home/ europapolitik/abstimmungen.html (accessed on 1 October 2017).

The Guardian. 2016. Switzerland makes U-turn over EU Worker Quotas to Keep Single Market Access. The Guardian, December 16.

Tobler, Christa. 2016. Eine einvernehmliche Schutzklausel für das Vereinigte Königreich: Hoffnung für die Schweiz? Jusletter, February 29.

Trommer, Silke. 2017. Post-Brexit Trade Policy Autonomy as Pyrrhic Victory: Being a Middle Power in a Contested Trade Regime. Globalizations 14: 810-19. [CrossRef]

UK Government. 2017. The United Kingdom's Exit from and New Partnership with the European Union; White Paper, Cm 9417; London: Department for Exiting the EU. Available online: https://www.gov.uk/government/uploads/system/uploads/attachment_data/file/589191/The_ United_Kingdoms_exit_from_and_partnership_with_the_EU_Web.pdf (accessed on 1 October 2017).

Welsh Government. 2017. Securing Wales' Future: Transition from the European Union to a New Relationship with Europe. January 23. Available online: https:/ / beta.gov.wales/sites/default/files/2017-02/31139\% 20Securing\%20Wales\%C2\%B9\%20Future_Version\%202_WEB.pdf (accessed on 1 October 2017).

(C) 2017 by the authors. Licensee MDPI, Basel, Switzerland. This article is an open access article distributed under the terms and conditions of the Creative Commons Attribution (CC BY) license (http:/ / creativecommons.org/licenses/by/4.0/). 